Article

\title{
Socioeconomic Impacts of Forest Fires upon Portugal: An Analysis for the Agricultural and Forestry Sectors
}

\author{
Vítor João Pereira Domingues Martinho ${ }^{1,2}$ \\ 1 Agricultural School (ESAV), Polytechnic Institute of Viseu (IPV), 3500-606 Viseu, Portugal; \\ vdmartinho@esav.ipv.pt \\ 2 Centre for Transdisciplinary Development Studies (CETRAD), University of Trás-os-Montes and Alto \\ Douro (UTAD), 5000-801 Vila Real, Portugal
}

Received: 2 December 2018; Accepted: 9 January 2019; Published: 13 January 2019

check for updates

\begin{abstract}
Recent forest fire activity has resulted in several consequences across different geographic locations where both natural and socioeconomic conditions have promoted a favorable context for what has happened in recent years in a number of countries, including Portugal. As a result, it would be interesting to examine the implications of forest fire activity in terms of the socioeconomic dynamics and performance of the agroforestry sectors in the context of those verified in the Portuguese municipalities. For this purpose, data from Statistics on Portugal was considered for output and employment from the business sector related to agricultural and forestry activities, which were disaggregated at the municipality level, for the period 2008-2015. Data for the burnt area was also considered in order to assess the impact of forest fires. The data was analyzed using econometric models in panel data based on the Keynesian (Kaldor laws) and convergence (conditional approaches) theories. The results from the Keynesian approaches show that there are signs of increasing returns to scale in the Portuguese agroforestry sectors, where the burnt area increased employment growth in agricultural activities and decreased employment in the forestry sector. Forest fires seem to create favorable conditions for agricultural employment in Portuguese municipalities and the inverse occurs for forestry employment. Additionally, some signs of convergence were identified between Portuguese municipalities for agroforestry output and employment, as well for the burnt areas. However, signs of divergence (increasing returns to scale) from the Keynesian models seem to be stronger. On the other hand, the evidence of beta convergence for the burnt areas are stronger than those verified for other variables, showing that the impacts from forest fires are more transversal across the whole country (however not enough to have sigma convergence).
\end{abstract}

Keywords: panel data; Portuguese municipalities; Keynesian models; convergence theory; regional resilience

JEL Classification: C23; E12; O13; O47; Q10

\section{Introduction}

Forest fires and their consequences came to be in several countries such as Portugal as a result of a set of factors related to the social, economic, environmental and natural contexts, which create favorable conditions or environments for these occurrences. They are realities towards which everyone may contribute, in some way, in order to mitigate them. In fact, damage caused by forest fires has increased over the last few decades across the globe [1].

In these frameworks, the scientific community may and should bring contributions, namely through new approaches and insights that allow for the prevention of the negative consequences from forest fires and allow us to understand the several impacts after their occurrence. Computational 
modelling, for example, brings new approaches for forest fire assessment, namely because it allows us to link several dimensions related with these multidisciplinary realities [2]. Good assessments of the impacts of forest fires are important contributions to the design of adjusted agroforestry policies, specifically in order to direct support to the most negatively affected activities. Policy instruments and related legislation are determinant tools for reducing the negative impacts of forest fires [3].

Indeed, in international terms, agroforestry land inside and outside of Europe continues to burn, in some cases with more severity and frequency, namely due to climate change and global warming. On the other hand, governments and related institutions create (and disclose) more regulations than in the past [4]. Maybe, new approaches are needed, where new technologies may play a determinant role. Multidisciplinary approaches could bring interesting contributions, for instance, economic analysis could transmit valuable insights.

These undesirable forest fires have always brought negative implications, however the impacts from these forest fires are not always equal across the several economic sectors [5]. These realities appeal for more highlights about the real consequences of forest fires across the different economic activities and across geographic levels/locations.

In this context, the main objective of this study is to analyze the impact of verified forest fires in Portugal over the period of 2008-2015 on the socioeconomic dynamics of the agricultural (agriculture, farming, hunting, and related service activities), forestry (forestry and forest exploration) and economic sectors. For this purpose, we considered data from Statistics Portugal [6] that was disaggregated at the municipality level for both output (gross value added) and employment (employed persons) from the business sector (all figures and tables are of one's own elaboration with data used from this database).

In other words, with this study, it is intended to investigate if forest fires reduce or increase agroforestry output and employment across Portuguese municipalities, over recent years, bringing insights for several stakeholders, namely for policymakers (both Portuguese and from the European Union), researchers and economic agents. The findings presented in this study will be another contribution for the policymakers to establish priorities in the design of forest fire regulations and for the perceptions of the economic agents about the socioeconomic implications from the wildfires. This analysis is fundamental for activities where profit margins are, often, lower and where it is crucial to create more employment and attract more people. The approaches and findings, here presented for Portugal, may be considered for other contexts around the world and, for example, promote the creation of a common forest policy in the European Union, putting together the several regulations created by the European institutions [4].

Considering these objectives, this analysis was based on Keynesian and convergence theories and the statistical information was analyzed through panel data. For the regressions, we considered the developments and the procedures proposed by Islam [7], Torres-Reyna [8] and Stata [9]. In each case, more adjusted methodologies were considered, taking into account the results for tests relating, namely, to heteroscedasticity and autocorrelation.

Keynesian and convergence approaches are developments from the economic growth theory and are useful to analyze performance and dynamics within economic sectors. Considering the objectives defined by this research, these approaches are adjusted towards the intended focus. In turn, the consideration of these theories in forest fire analysis may be explored further. Subsequent explanations about the Keynesian and convergence frameworks will be presented in Section 3.

The need for more socioeconomic research relating to forest fires, for Portugal, has been identified in previous studies (as in, for example, Navalho et al. [10]) and the work presented here aims to contribute towards filling this gap.

Considering the objectives and methodologies adopted for the research presented here, this study will be structured, after this introduction, in a further six parts. The next section is a literature review, the third section is for the explanation of methodology, the fourth for the data description, the fifth and sixth for the results obtained from the Keynesian and convergence approaches, respectively, and finally the last section is for the main conclusions. 


\section{Literature Insights}

In countries like Portugal and Spain, recent years have shown that the consequences of forest fires may be dramatic, with an inclusive loss of human lives and firms. The implications of forest fire activity in the social and economic context in certain geographic regions is enormous $[11,12]$ and some areas will require several years for normality to be restored. In fact, the occurrence and severity of forest fires, as well as their relevant impact on various levels of human life, has become a concern for several stakeholders and policymakers in a variety of global locations [13].

The negative consequences of forest fires are, indeed, relevant across different areas of human life, inclusively affecting the normal conditions for human health [14]. In some contexts, forest fires are the main agent of disturbances having a more random spatial spreading [15], making it more difficult to predict the consequences. One of the main challenges for national authorities in some countries is to predict the implications on human survival from forest fires in more isolated regions.

To mitigate the potentially devastating consequences of forest fires, prevention is especially important, in particular through the reduction of the available fuel load [16]. However, it is also crucial to ensure that resources are immediately available for firefighting [17], and because some natural elements, such as changing winds, may render other existing factors irrelevant [18]. Adjusted forest fire management with balanced prevention and suppression approaches are crucial to reduce the negative impacts of these agents on forest disturbance.

In some circumstances the resilience of certain plants may make all the difference in reducing the impacts of forest fires, namely in the new context of climate change $[19,20]$. This question should be considered by the several agroforestry stakeholders, namely by policymakers, to design adjusted plans for forest management. In any case, the relationships between climate change, global warming and forest fires seem to be, in some cases, correlated [21].

During the post-fire period, it is important to quickly assess the implications [22,23] as a means to readily promote adjusted policies that will reduce these negative impacts from fires and support a quick recovery of the socioeconomic contexts and affected ecosystems.

In any case, avoiding the occurrence of forest fires altogether seems to be the most important factor and prevention plays a fundamental role. Fuel load reduction is important, but it is also crucial to make an adjusted assessment of the risks and critical periods which contribute to forest fire occurrence [24].

\section{Methodology Explanation}

From the Keynesian theory, we drew from the Verdoorn [25] and Kaldor's [26,27] developments, primarily those related to the Kaldor coefficient. The Kaldor coefficient, which we obtained from running regressions with employment growth as a function of output growth, captures the dynamic effects of economies of scale where we expect a coefficient value between 0 and 1 , where values closer to 0 indicate stronger, increasing returns to scale. In this study, this relationship was enlarged using a variable related to forest fire severity (i.e., burnt area) as a way of assessing the effect of forest fires on the socioeconomic dynamics of the Portuguese municipalities. The enlargement of this Kaldor equation and its application for use in several economic sectors, including agricultural activities, has already been implemented in other work, such as Martinho [28,29]. Indeed, the Verdoorn and Kaldor developments are increasingly relevant in the current global economic context and bring insight to both regional development [30-33], of labor contexts [34,35] and the relationship between manufacturing and economic development [36].

In relation to the convergence theory, we considered the approaches related to absolute (unconditional) and conditional convergence [37-43]. The idea behind absolute convergence is that all countries or regions tend to converge to the same steady-state of economic development (for example, gross domestic product per capita). In turn, the conditional convergence approach defends the notion that convergence is dependent on the condition/state of the countries or regions. In this case, countries with similar contexts (for example, similar capital human accumulation) can converge at the same steady-state, defending the existence of different steady-states and the 
concept of clubs of convergence, meaning groups of countries that converge to the same level of development. In general, the convergence trends in this theory are analyzed through determining the sigma convergence (measured through the coefficient of variationaverage standard deviation by the mean) and beta convergence (coefficient of regression, expected negative for convergence). In practice, the sigma convergence analyses, for a given variable, the tendency of convergence/divergence over a period of time and across the several municipalities (for the case presented in this study). If there is a decreasing/increasing trend, over the period considered, in the coefficient of variation there is convergence/divergence. The beta convergence reveals the annual rate of convergence. In this way, the convergence theory argues that the beta convergence (annual convergence) is necessary, but not sufficient to guarantee sigma convergence (convergence over the period). These concepts have several applications in current times [44]. The implementation of approaches related to convergence theory in the agroforestry sector has been performed in several studies, for example, in Martinho [45] and others [46,47].

\section{Data Description}

Figure 1 shows that after 2011, there was continual growth in the agricultural business output (averaged across the Portuguese municipalities) after a relatively stable trend from 2008. The average growth of the forestry business output reveals a decreasing trend until 2012 and a strong increase after 2013. It's important to stress that these values for the output from the Portuguese agroforestry sectors were deflated with the consumer prices index disaggregated at NUTS (Nomenclature of territorial units for statistics) 2 level (the finest disaggregation available). We used the consumer price index from unprocessed food to deflate the municipality agricultural output and the consumer price index without housing to deflate the municipality forestry output.

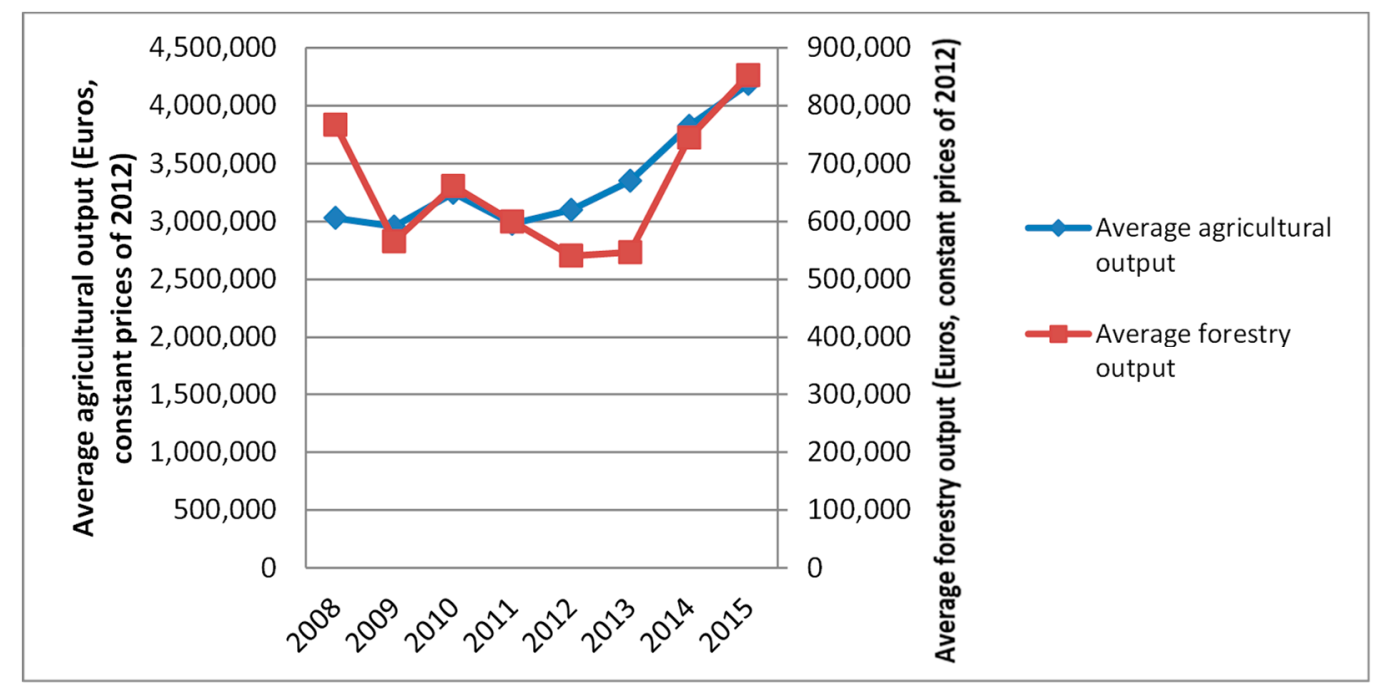

Figure 1. Average output for the agroforestry sectors across the Portuguese municipalities over the period 2008-2015.

Relative to agroforestry employment, Figure 2 shows that this variable increased strongly after 2012 following a stable tendency from 2008. It seems that the Portuguese economic crisis had a positive effect on the agroforestry municipal dynamics, both in terms of output and employment. In fact, the agroforestry sector in Portugal has a great potential for growth, however, due to several factors, some of which are historic, sometimes this sector is forgotten about along with its potential for a more sustainable social, economic and environmental development. The creation of a common forest policy in the European Union interconnected with common agricultural policy could potentially bring about more interesting contributions for agroforestry performance. 


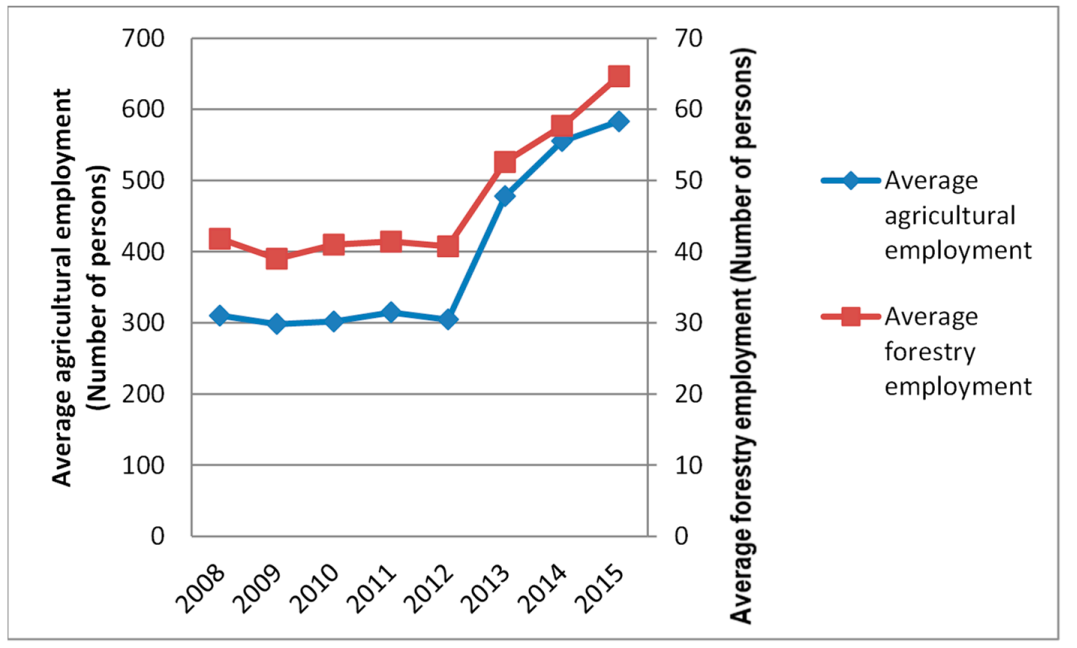

Figure 2. Average employment for the agroforestry sectors across the Portuguese municipalities over the period 2008-2015.

Figure 3 reveals that over the period 2008-2015, the years of 2010 and 2013 showed the greatest average burnt area. On the other hand, the years 2008 and 2014 showed the least severe average forest fire activity over the period in the Portuguese municipalities. As referred to before in the literature review, forest fire occurrences and severities have more of a time and spatial random distribution. This random behavior makes it more difficult to predict the forest fires' occurrences and consequences.

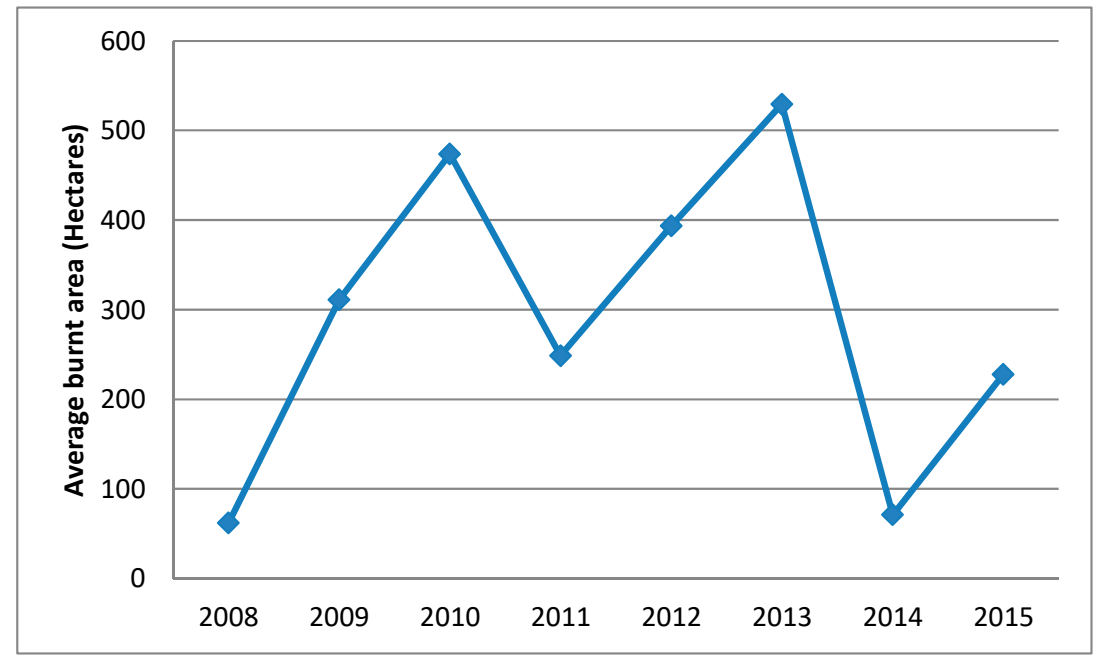

Figure 3. Average burnt area across the Portuguese municipalities over the period 2008-2015.

\section{Results Obtained through the Keynesian Developments}

The results presented in Table 1 which were obtained using the Kaldor equation through panel data methodologies for the agricultural sector, highlight the strong increasing returns to scale observed. In fact, the Kaldor coefficient (the coefficient for the output growth) is close to 0 (this could also be obtained by measuring the difference between 1 and the Verdoorn coefficient) which, as previously explained, is a sign of robust scale economies. On the other hand, this Table shows that the amount of burnt area may have had a favorable effect on employment growth within the agricultural sector. This is a curious result that needs further analysis in future research. In fact, it will be important to understand in future studies just how the burnt areas contribute towards increases in agricultural employment growth. In any case, some of the burnt areas may indeed be used for agricultural activities, thus improving the social contribution of the farming sector. 
Table 1. Kaldor equation enlarged regression, for the agricultural sector, with the employment growth as a function of the output growth across the Portuguese municipalities.

\begin{tabular}{cc}
\hline & Period 2008-2015 \\
\hline Model & Panels Corrected Standard Errors \\
\hline Constant & $-0.147^{*}$ \\
& $(-3.860)$ \\
Output growth & {$[0.000]$} \\
& $0.038^{*}$ \\
& $(3.330)$ \\
Burnt area logarithm & {$[0.001]$} \\
& $0.069^{*}$ \\
Hausman test & $(5.520)$ \\
Modified Wald test for group wise & $0.000]$ \\
Wooldridge test for autocorrelation & 1.990 \\
\end{tabular}

Note: * statistically significant at $1 \%$.

The results from the forestry sector outlined in Table 2 reveal that although the economies of scale are slightly weaker in the forestry sector (coefficient around 0.041) than in the agricultural sector, they are, nevertheless, strong. In turn, this Table reports that, as expected, the burnt area has a negative impact on forestry employment growth (however, with a level of significance at $10 \%$ ). Indeed, the main directly affected activities with forest fires are those related with the forestry sector. This reduction in forestry employment as a consequence of forest fires should be taken into account by the policymakers, namely because of the social and economic problems verified in the most affected areas (often located in rural and unfavorable Portuguese regions).

Table 2. Kaldor equation enlarged regression for the forestry sector, with the employment growth as a function of the output growth across the Portuguese municipalities.

\begin{tabular}{cc}
\hline & Period 2008-2015 \\
\hline Model & Robust Random Effects \\
\hline & -0.033 \\
& $(-0.920)$ \\
Output growth & {$[0.360]$} \\
& $0.041^{*}$ \\
& $(3.540)$ \\
Burnt area logarithm & {$[0.000]$} \\
& $-0.015^{* *}$ \\
Hausman test & $(-1.910)$ \\
& {$[0.056]$} \\
Modified Wald test for group wise & 2.230 \\
Wooldridge test for autocorrelation & {$[0.328]$} \\
\hline Note: ${ }^{*}$ statistically significant at $1 \% ;{ }^{* *}$ statistically significant at $10 \%$.
\end{tabular}

The strong increasing returns found for the agroforestry sectors are unexpected considering the Kaldor developments, however it is namely the way the agricultural sector has performed over recent years which has promoted an important increase in its dynamics and this explains in part these results obtained. 


\section{Results for the Absolute and Conditional Convergence}

In regards to sigma convergence, Figure 4 shows that the agricultural output reveals a divergence tendency over the period considered and across the Portuguese municipalities, with signs of convergence in 2011, 2013, and 2014. This reveals that the agricultural output over the period taken into account agglomerated in some Portuguese municipalities. In turn, the forestry output shows a trend of convergence over 2008-2015, presenting that the output from forestry activities does not follow a trend of agglomeration in some municipalities (the spatial distribution is more homogeneous).

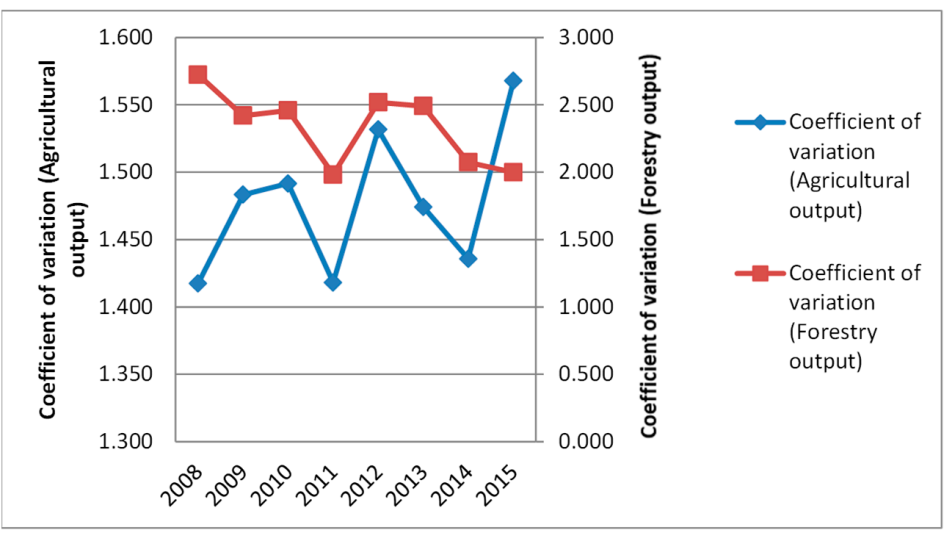

(a) Coefficient of variation for agricultural and forestry output

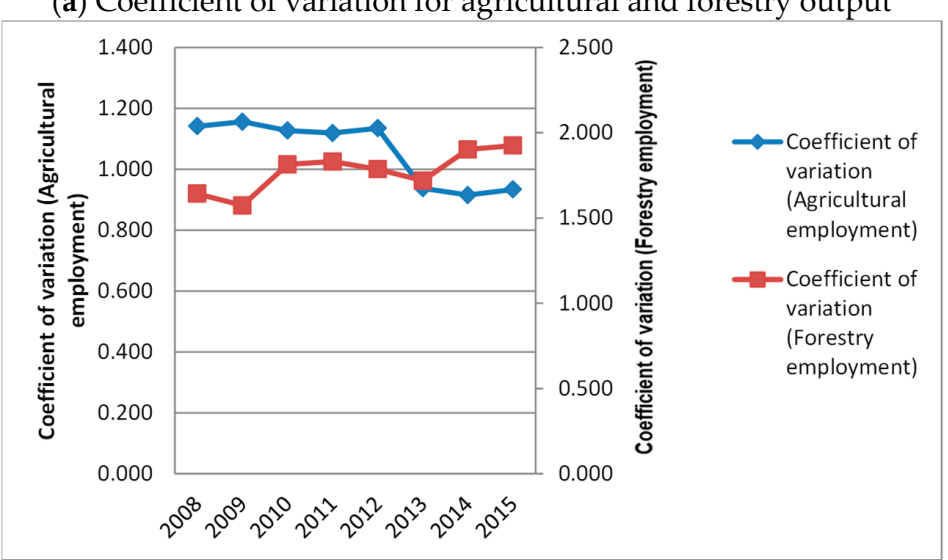

(b) Coefficient of variation for agricultural and forestry employment

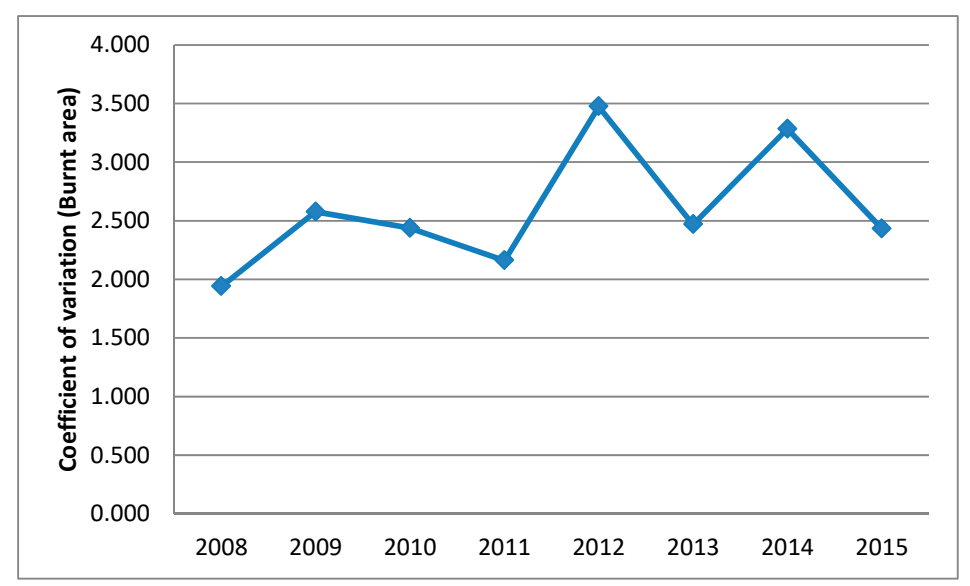

(c) Coefficient of variation for burnt area

Figure 4. Sigma convergence across the Portuguese municipalities over the period 2008-2015.

Relative to agroforestry employment, the tendencies of divergence/convergence are the opposite of those verified for the output. Indeed, agricultural employment shows signs of convergence and 
forestry employment shows evidence of divergence. These trends for the agroforestry output and employment confirm the signs of increasing returns found before for the relationships between these two variables.

Finally, the burnt area, in general, shows signs of divergence over the examined period, showing that the impact of forest fires are concentrated in some municipalities, with the exception of some convergence in 2010, 2011, 2013, and 2015 (2008 and 2011 were the years with less burnt area, as shown in Figure 3).

In regards to beta convergence, the results for the coefficient of convergence are presented in Tables 3-7 for the agricultural (output and employment) and forestry (output and employment) sectors and for the burnt area. In each case (output, employment, and burnt area) we ran, only, one regression to analyze the conditional convergence. The results are not presented here for the absolute convergence, because the results for the coefficient of convergence are similar (to those presented for the conditional convergence) and to avoid presenting an exaggerated number of tables. For analyzing output and employment, we considered the burnt area (in logarithms or in growth) as a conditional variable. In our analysis of the burnt area, the conditional variable was forestry employment growth (to deeper analyze the relationships between forest fires and forestry dynamics).

Table 3. Conditional convergence regression for agricultural output with the logarithms difference as a function of the logarithm in the previous year, across the Portuguese municipalities.

\begin{tabular}{cc}
\hline & Period 2008-2015 \\
\hline Model & Panels Corrected Standard Errors \\
\hline & $0.730 *$ \\
& $(3.950)$ \\
& {$[0.000]$} \\
Output logarithm in the previous year & $-0.048^{*}$ \\
& $(-4.080)$ \\
Burnt area logarithm & {$[0.000]$} \\
& 0.001 \\
Hausman test & $(0.300)$ \\
& {$[0.765]$} \\
Modified Wald test for group wise & $430.420{ }^{*}$ \\
Wooldridge test for autocorrelation & {$[0.000]$} \\
Note: ${ }^{*}$ statistically significant at $1 \%$. & Yes \\
\hline
\end{tabular}

Table 4. Conditional convergence regression for agricultural employment with the logarithms difference as a function of the logarithm in the previous year across the Portuguese municipalities.

\begin{tabular}{cc}
\hline & Period 2008-2015 \\
\hline Model & Panels Corrected Standard Errors \\
\hline & $0.310^{*}$ \\
& $(5.670)$ \\
Emplontant & {$[0.000]$} \\
& $-0.052^{*}$ \\
Burnt area logarithm & $(-5.600)$ \\
& {$[0.000]$} \\
Hausman test & $0.022^{*}$ \\
& $(5.180)$ \\
Modified Wald test for group wise & {$[0.000]$} \\
Wooldridge test for autocorrelation & $26.320^{*}$ \\
\hline
\end{tabular}

Note: * statistically significant at $1 \%$. 
Table 5. Conditional convergence regression for forestry output with the logarithms difference as a function of the logarithm in the previous year, across the Portuguese municipalities.

\begin{tabular}{cc}
\hline & Period 2008-2015 \\
\hline Model & Panels Corrected Standard Errors \\
\hline & $1.599^{*}$ \\
& $(5.920)$ \\
& {$[0.000]$} \\
Output logarithm in the previous year & $-0.121^{*}$ \\
& $(-6.020)$ \\
Burnt area growth & {$[0.000]$} \\
& $-0.000^{* *}$ \\
Hausman test & $(-2.000)$ \\
Modified Wald test for group wise & {$[0.046]$} \\
Wooldridge test for autocorrelation & $268.060^{*}$ \\
\hline
\end{tabular}

Note: * statistically significant at $1 \%$; ** statistically significant at $5 \%$.

Table 6. Conditional convergence regression for forestry employment with the logarithms difference as a function of the logarithm in the previous year, across the Portuguese municipalities.

\begin{tabular}{cc}
\hline & Period 2008-2015 \\
\hline Model & Panels Corrected Standard Errors \\
\hline & $0.145^{*}$ \\
& $(4.350)$ \\
Emplont & {$[0.000]$} \\
& $-0.021^{*}$ \\
Burnt area growth & $(-2.930)$ \\
& {$[0.003]$} \\
Hausman test & -0.005 \\
& $(-1.360)$ \\
Modified Wald test for group wise & {$[0.173]$} \\
Wooldridge test for autocorrelation & $102.310^{*}$ \\
\end{tabular}

Note: * statistically significant at $1 \%$.

Table 7. Conditional convergence regression for the burnt area with the logarithms difference as a function of the logarithm in the previous year, across the Portuguese municipalities.

\begin{tabular}{cc}
\hline & Period 2008-2015 \\
\hline Model & Panels Corrected Standard Errors \\
\hline & $1.832^{*}$ \\
Constant & $(15.860)$ \\
& {$[0.000]$} \\
Burnt area logarithm in the previous year & $-0.450^{*}$ \\
& $(-16.530)$ \\
Forestry employment growth & {$[0.000]$} \\
& $-0.348^{*}$ \\
Hausman test & $(-3.260)$ \\
Modified Wald test for group wise & {$[0.001]$} \\
Wooldridge test for autocorrelation & $779.490 *$ \\
\end{tabular}

Note: * statistically significant at $1 \%$. 
Table 3 (representing conditional convergence for the agricultural output) shows that there are statistically significant and relevant signs of convergence (negative coefficient of regression and around 0.048). Comparing this result with that obtained before for the sigma convergence (Figure 4) it is noted that the beta convergence is not enough to have sigma convergence (the beta convergence is a necessary condition, but not sufficient, to have sigma convergence). The conditional variable (burnt area logarithm) is not statistically significant, revealing that the convergence seems to be absolute in this analysis.

Table 4 shows that the signs of convergence are stronger for agricultural employment (coefficient of regression negative and around 0.055) than those found for agricultural output, which are in line with the results found for the sigma convergence (Figure 4). The Table reveals that in this case, the convergence is conditional, and the burnt area logarithm has a positive impact on agricultural employment growth (confirming the results described earlier for the Keynesian analysis). In fact, these results confirm the findings obtained before for the Keynesian analysis, showing that the burnt area does not have any impact on the agricultural output, but improves agricultural employment.

The convergence analysis for the forestry output (Table 5) presents strong signs of convergence (around -0.121) and shows that the effect of the conditional variable (burnt area logarithm) is negligible and close to zero. These results reveal that, as with for agricultural output, the convergence for forestry output seems to be absolute (considering the negligible value for the coefficient of the burnt area). These stronger signs of convergence for the forestry output confirm the results obtained before for the sigma convergence.

The convergence indications for forestry employment (Table 6) are weaker than those found for the forestry output, which is in line with the results outlined in Figure 4, and the conditional variable is not statistically significant. It is worth stressing that the results obtained up to this point show that forest fires (through the burnt area) have little impact on the performance and dynamics of the Portuguese agroforestry sectors, considering the results obtained for the burnt area coefficient in the several estimations. The only evident and statistically significant impact from the burnt area is a positive effect on agricultural employment.

Table 7 shows that there are strong signs of convergence for the burnt area across the Portuguese municipalities, however they are not enough to have sigma convergence (Figure 4). On the other hand, the convergence in the burnt area is conditional toward forestry employment growth, showing that the burnt area growth is negatively influenced by employment growth from the forestry sector. This seems to indicate that bringing more people to forest areas may be an interesting solution in reducing the severity of forest fires. This is an important finding that should be considered by the several stakeholders, namely by the national authorities. It is important to bring new activities for the agroforestry sector and here the policies related with innovation and entrepreneurship may provide an important contribution.

\section{Discussions}

The objective of this study was to analyze the socioeconomic implications of forest fires in the Portuguese municipalities' agroforestry business sectors over the period 2008-2015, by considering data from Statistics Portugal for output, employment, and burnt area. The statistical information was analyzed with panel data methodologies, namely those derived from Keynesian and convergence theories.

The data analysis shows that, in general, after 2011/2012, output and employment increased on average at a persistent trend in the agroforestry sectors of the Portuguese municipalities. The Portuguese economic crisis has also borne its influence here. In fact, some of the unemployment generated in other sectors, namely in the industry and construction, found solutions within the agroforestry sectors [48]. On the other hand, over the period we considered, the trend for the average burnt area is essentially white noise, demonstrating neither an increasing or decreasing trend and 
showing the great irregularity in the impact of forest fires in the Portuguese context. The forest fires are agents of landscape disturbances with a great degree of unpredictability [15].

The Keynesian analysis, using the Verdoorn-Kaldor developments, reveals that there are strong increasing returns in the Portuguese agroforestry sectors, which are higher in the agricultural sector. These findings are in line with other works [32]. On the other hand, considering the enlarged Kaldor equation, the burnt area logarithm positively influences employment growth in the agricultural sector and negatively influences the forestry sector. Forest fires seem to have a positive impact on the number of people employed in the Portuguese agricultural sector. The modernization of the agricultural sector seen in recent years seems to have had a positive impact on the dynamics and performance of the sector, creating the right circumstances to absorb the workforce released by other diminishing sectors [48].

The convergence research, considering both the absolute and conditional approaches, was performed using the sigma and beta convergence concepts, following, for example, He et al. [46] and Spirkova et al. [47]. The sigma convergence shows signs of a convergence trend for forestry output and agricultural employment. The beta convergence analysis (coefficient of regression) shows that the convergence is more absolute than conditional, with the exception of agricultural employment convergence where, again, the burnt area logarithm (conditional variable) positively influences agricultural employment growth. On the other hand, burnt area growth is negatively influenced by forestry employment growth, showing the importance of increased forestry activities in forest fire prevention.

Additionally, it is worth noting the strong trends of agglomeration (strong increasing returns to scale from the Keynesian analysis) in the agricultural and forestry sectors over the period considered and across the Portuguese municipalities, showing that the Portuguese agroforestry activities became more concentrated in some municipalities in this period [49]. On the other hand, there are signs of beta convergence (not as strong as the evidence of agglomeration) that are not enough to guarantee sigma convergence. In practice it seems that there are strong signs of divergence in the output and employment from the Portuguese agroforestry sectors, as well as in the burnt area. This may be a consequence of land abandonment and of desertification of the interior of Portugal [10].

The study presented here brings interesting insights into the understanding of forest fires, for policymakers and the perceptions of several stakeholders. It is important to bring new and multidisciplinary approaches for the forest fires contexts around the world, namely to improve regional resilience. For this it is important to increase economic dynamics in the rural area in a sustainable way, and to create more employment to attract younger people.

\section{Conclusions and Political Implications}

As a final remark, one should highlight that the impact of forest fires (burnt area) on the Portuguese agroforestry dynamics and performance seems too moderate. In fact, forest fires seem to improve agricultural employment with coefficients of around 0.069 (from the Keynesian approach) and 0.022 (form the convergence theory). On the other hand, forest fires show some evidence of reducing forestry employment, presenting a coefficient of -0.015 (from the Keynesian theory), though with a statistical significance at $10 \%$. The impact on agroforestry output seems to be residual or negligible.

In terms of political implications, it is important to bring about more activities for the forestry sector in order to reduce the risk of forest fires and to improve the dynamics of this sector (the results show lower scale economies relative to the agricultural sector). On the other hand, it will be important to continue agricultural modernization and its performance to better absorb the labor force released by other sectors. The creation of a common forest policy interconnected with a common agricultural policy, incorporating innovation and entrepreneurship strategies could be an interesting approach. To avoid desertification and land abandonment there should be a priority in the design of new policies. Considering the dimensions of the consequences of forest fires, the related policies must reconsider the relevance given to the socioeconomic impact on the agroforestry sector, where the negative impacts 
seem to be residual. In any case, the Portuguese agroforestry sector does have several problems, however, they are not a direct consequence of forest fires.

These insights open up new fields of research. In this way, for future studies, it will be important to understand the main factors which create the conditions for forest fires to inadvertently promote agricultural employment. Migration of the workforce from forestry to agriculture may provide an explanation. On the other hand, it will be interesting to further investigate the strong impact of the burnt area on agricultural employment, rather than agricultural output. Considering the negative socioeconomic implications of forest fires evidenced by the literature [11,12], it will also be important to identify the main factors that allow for negative impacts in the agroforestry sector from the Portuguese municipalities to be weak.

Funding: This work is supported by national funds, through the FCT-Portuguese Foundation for Science and Technology under the project UID/SOC/04011/2019.

Acknowledgments: I would like to thank the anonymous reviewers and all those who have contributed, in some way, to this work.

Conflicts of Interest: The author declares no conflict of interest.

\section{References}

1. Hallema, D.W.; Robinne, F.-N.; Bladon, K.D. Reframing the Challenge of Global Wildfire Threats to Water Supplies. Earth Future 2018, 6, 772-776. [CrossRef]

2. Snitker, G. Identifying natural and anthropogenic drivers of prehistoric fire regimes through simulated charcoal records. J. Archaeol. Sci. 2018, 95, 1-15. [CrossRef]

3. Majlingova, A.; Sedliak, M.; Smrecek, R. Spatial distribution of surface forest fuel in the Slovak Republic. J. Maps 2018, 14, 368-372. [CrossRef]

4. San-Miguel-Ayanz, J.; Durrant, T.; Boca, R.; Libertà, G.; Branco, A.; de Rigo, D.; Ferrari, D.; Maianti, P.; Vivancos, T.A.; Schulte, E.; et al. Forest Fires in Europe, Middle East and North Africa 2016; EUR 28707 EN, Publications Office: Luxembourg, 2017.

5. Munoz-Robles, C.; Santana-Arias, R. Fire hotspots in Sierra Madre Oriental, San Luis Potosi: Spatial patterns and related factors. Madera Bosques 2018, 24, e2411565.

6. INE Statistics Portugal. Available online: https://www.ine.pt/xportal/xmain?xpgid=ine_main\&xpid=INE (accessed on 19 December 2017).

7. Islam, N. Growth Empirics: A Panel Data Approach. Q. J. Econ. 1995, 110, 1127-1170. [CrossRef]

8. Torres-Reyna, O. Panel Data Analysis Fixed and Random Effects using Stata (v. 4.2). Available online: https:/ / www.princeton.edu/ \{\}otorres/Panel101.pdf (accessed on 19 December 2017).

9. Stata Stata: Data Analysis and Statistical Software. Available online: https://www.stata.com/ (accessed on 19 December 2017).

10. Navalho, I.; Alegria, C.; Quinta-Nova, L.; Fernandez, P. Integrated planning for landscape diversity enhancement, fire hazard mitigation and forest production regulation: A case study in central Portugal. Land Use Pol. 2017, 61, 398-412. [CrossRef]

11. Slezakova, K.; Morais, S.; do Pereira, M.C. Forest fires in Northern region of Portugal: Impact on PM levels. Atmos. Res. 2013, 127, 148-153. [CrossRef]

12. Armenteras, D.; Gibbes, C.; Vivacqua, C.A.; Sebastian Espinosa, J.; Duleba, W.; Goncalves, F.; Castro, C. Interactions between Climate, Land Use and Vegetation Fire Occurrences in El Salvador. Atmosphere 2016, 7 , 26. [CrossRef]

13. Moeltner, K.; Kim, M.-K.; Zhu, E.; Yang, W. Wildfire smoke and health impacts: A closer look at fire attributes and their marginal effects. J. Environ. Econ. Manag. 2013, 66, 476-496. [CrossRef]

14. Kim, Y.; Knowles, S.; Manley, J.; Radoias, V. Long-run health consequences of air pollution: Evidence from Indonesia's forest fires of 1997. Econ. Hum. Biol. 2017, 26, 186-198. [CrossRef]

15. Boucher, Y.; Perrault-Hebert, M.; Fournier, R.; Drapeau, P.; Auger, I. Cumulative patterns of logging and fire (1940-2009): Consequences on the structure of the eastern Canadian boreal forest. Landsc. Ecol. 2017, 32, 361-375. [CrossRef] 
16. Collins, R.D.; de Neufville, R.; Claro, J.; Oliveira, T.; Pacheco, A.P. Forest fire management to avoid unintended consequences: A case study of Portugal using system dynamics. J. Environ. Manag. 2013, 130, 1-9. [CrossRef] [PubMed]

17. Castillo, M.E.; Rodriguez y Silva, F. Determining response times for the deployment of terrestrial resources for fighting forest fires. A case study: Mediterranean—Chile. Cienc. Investig. Agrar. 2015, 42, 97-107. [CrossRef]

18. Jin, Y.; Goulden, M.L.; Faivre, N.; Veraverbeke, S.; Sun, F.; Hall, A.; Hand, M.S.; Hook, S.; Randerson, J.T. Identification of two distinct fire regimes in Southern California: Implications for economic impact and future change. Environ. Res. Lett. 2015, 10, 094005. [CrossRef]

19. Hammill, K.; Penman, T.; Bradstock, R. Responses of resilience traits to gradients of temperature, rainfall and fire frequency in fire-prone, Australian forests: Potential consequences of climate change. Plant Ecol. 2016, 217, 725-741. [CrossRef]

20. Costa, F.V.; Blüthgen, N.; Viana-Junior, A.B.; Guerra, T.J.; Di Spirito, L.; Neves, F.S. Resilience to fire and climate seasonality drive the temporal dynamics of ant-plant interactions in a fire-prone ecosystem. Ecol. Indic. 2018, 93, 247-255. [CrossRef]

21. Alexander, H.D.; Mack, M.C. A Canopy Shift in Interior Alaskan Boreal Forests: Consequences for Aboveand Belowground Carbon and Nitrogen Pools during Post-fire Succession. Ecosystems 2016, 19, 98-114. [CrossRef]

22. Vega, J.; Jimenez, E.; Vega, D.; Ortiz, L.; Perez, J.R. Pinus pinaster Ait. tree mortality following wildfire in Spain. For. Ecol. Manag. 2011, 261, 2232-2242. [CrossRef]

23. Kurbanov, E.; Vorobyev, O.; Leznin, S.; Polevshikova, Y.; Demisheva, E. Assessment of burn severity in Middle Povozhje with Landsat multitemporal data. Int. J. Wildland Fire 2017, 26, 772-782. [CrossRef]

24. Pereira Torres, F.T.; Ribeiro, G.A.; Martins, S.V.; Lima, G.S. Determination of the Most Favorable Period for the Occurrences of Vegetation Fires in the Urban Area of Juiz De Fora, Mg. Rev. Árvore 2010, 34, 297-303.

25. Verdoorn, P.J. Fattori Che Regolano lo Sviluppo Della Produttività Del Lavoro. L'Industria 1949, 1, 45-53.

26. Kaldor, N. Causes of the Slow Rate of Economic Growth of the United Kingdom; Cambridge University Press: Cambridge, UK, 1966.

27. Kaldor, N. Strategic Factors in Economic Development; New York State School of Industrial and Labor Relations, Cornell University: Ithaca, NY, USA, 1967.

28. Martinho, V.J.P.D. The Agricultural Economics of the 21st Century; Martinho, V.J.P.D., Ed.; Springer International Publishing: Basel, Switzerland, 2015; ISBN 978-3-319-09471-7.

29. Martinho, V.J.P.D. Energy consumption across European Union farms: Efficiency in terms of farming output and utilized agricultural area. Energy 2016, 103, 543-556. [CrossRef]

30. Leon-Ledesma, M.A. Verdoorn's Law and increasing returns: An empirical analysis of the Spanish regions. Appl. Econ. Lett. 1999, 6, 373-376. [CrossRef]

31. Millemaci, E.; Ofria, F. Supply and demand-side determinants of productivity growth in Italian regions. Struct. Chang. Econ. Dyn. 2016, 37, 138-146. [CrossRef]

32. Martinho, V.J.P.D. Efficiency, total factor productivity and returns to scale in a sustainable perspective: An analysis in the European Union at farm and regional level. Land Use Pol. 2017, 68, 232-245. [CrossRef]

33. Postiglione, P.; Andreano, M.S.; Benedetti, R. Spatial Clusters in EU Productivity Growth. Growth Chang. 2017, 48, 40-60. [CrossRef]

34. Dosi, G.; Pereira, M.C.; Roventini, A.; Virgillito, M.E. When more flexibility yields more fragility: The microfoundations of Keynesian aggregate unemployment. J. Econ. Dyn. Control 2017, 81, 162-186. [CrossRef]

35. Podkaminer, L. Labour Productivity Growth Slowdown: An Effect of Economic Stagnation Rather Than Its Cause? Acta. Oecon. 2017, 67, 67-77. [CrossRef]

36. Marconi, N.; de Borja Reis, C.F.; de Araujo, E.C. Manufacturing and economic development: The actuality of Kaldor's first and second laws. Struct. Chang. Econ. Dyn. 2016, 37, 75-89. [CrossRef]

37. Solow, R.M. A Contribution to the Theory of Economic Growth. Q. J. Econ. 1956, 70, 65-94. [CrossRef]

38. Romer, P.M. Increasing Returns and Long-Run Growth. J. Political Econ. 1986, 94, 1002-1037. [CrossRef]

39. Lucas, R.E. On the mechanics of economic development. J. Monet. Econ. 1988, 22, 3-42. [CrossRef]

40. Romer, P.M. Endogenous Technological Change. J. Political Econ. 1990, 98, 71-102. [CrossRef]

41. Barro, R.J. Economic Growth in a Cross Section of Countries. Q. J. Econ. 1991, 106, 407-443. [CrossRef]

42. Barro, R.; Sala-i-Martin, X. Convergence across States and Regions. Brook. Pap. Econ. Act. 1991, 22, $107-182$. [CrossRef] 
43. Barro, R.J. Convergence and Modernization Revisited; National Bureau of Economic Research: Cambridge, MA, USA, 2012.

44. Chambers, D.; Dhongde, S. Are countries becoming equally unequal? Empir. Econ. 2017, 53, $1323-1348$. [CrossRef]

45. Martinho, V.J.P.D. The Reality for Agricultural Economics Within the European Union: Stressing the Efficiency Indicators Across the Representative Farms; Springer Briefs in Agriculture; Springer International Publishing: Basel, Switzerland, 2017.

46. He, Y.; Xie, H.; Fan, Y.; Wang, W.; Xie, X. Forested Land Use Efficiency in China: Spatiotemporal Patterns and Influencing Factors from 1999 to 2010. Sustainability 2016, 8, 772. [CrossRef]

47. Spirkova, D.; Stehlikova, B.; Zubkova, M.; Sevela, M.; Stiglic, D. Evaluation of Agriculture's Economic Role in EU Countries. Ekonomicky Casopis 2017, 65, 763-779.

48. Eichenbaum, M.; Rebelo, S.; de Resende, C. The Portuguese Crisis and the IMF; IEO Background Paper; Independent Evaluation Office, International Monetary Fund: Washington, DC, USA, 2016.

49. Martinho, V.J.P.D. Output Impacts of the Single Payment Scheme in Portugal: A Regression with Spatial Effects. Outlook Agric. 2015, 44, 109-118. [CrossRef]

(C) 2019 by the author. Licensee MDPI, Basel, Switzerland. This article is an open access article distributed under the terms and conditions of the Creative Commons Attribution (CC BY) license (http://creativecommons.org/licenses/by/4.0/). 